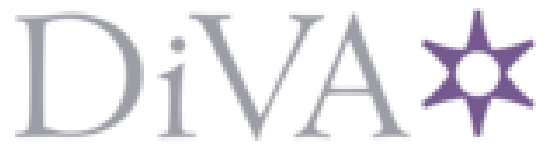

http://www.diva-portal.org

This is the published version of a paper published in .

Citation for the original published paper (version of record):

Lindholm, K-J., Ersmark, E., Hennius, A., Lindgren, S., Loftsgarden, K. et al. (2021)

Contesting Marginality: The Boreal Forest of Middle Scandinavia and the Worlds

Outside

The Medieval Globe, 7(1): 9-34

Access to the published version may require subscription.

N.B. When citing this work, cite the original published paper.

Permanent link to this version:

http://urn.kb.se/resolve?urn=urn:nbn:se:kau:diva-87197 


\title{
CONTESTING MARGINALITY: THE BOREAL FOREST OF MIDDLE SCANDINAVIA AND THE WORLDS OUTSIDE
}

\author{
KARL-JOHAN LINDHOLM, ERIK ERSMARK, ANDREAS HENNIUS, \\ SAKARIAS LINDGREN, KJETIL LOFTSGARDEN, and EVA SVENSSON*
}

MORE THAN HALF of Scandinavia's land area consists of boreal forest. This environment is characterized by a hilly and undulating topography interspersed by numerous lakes, rivers, streams, and mires. From the perspective of today's urban-centred world, or if compared to the major waterways and coastal ports where connectivity and global encounters are clearly apparent, the Scandinavian inlands appear marginal. This mistaken notion, we argue, is one of the main reasons for a general scarcity of research on the history of inland Scandinavia, a fate shared by other so-called marginal landscapes in Europe. ${ }^{1}$ Although archaeological research has repeatedly demonstrated connections between the exploitation of frontier "outlands," on the one hand, and agricultural plains and coastal areas on the other, the boreal forests have hitherto been considered of negligible importance for understanding the larger societal developments of the past. Not only do they lack the presence of social elites in the archaeological record and produce little written documentation prior to $1500 \mathrm{CE}$, the first permanent agrarian settlements have generally been perceived as belonging to the Viking Age (ca. 750-1050 CE) or the central and later Middle Ages (ca. 1050-1520 CE), and their presence has been explained as a result of population growth in the central agricultural regions and the new technologies that facilitated farming in forested areas. ${ }^{2}$ In consequence, their history has largely been written on the basis of an anachronistic archaeology looking ahead to the historical and ethnographic situation of the early modern and modern eras.

This view, however, is now being challenged by a growing body of archaeological data supplemented by an increasing number of studies based on modern methods. For

\footnotetext{
* This article represents the findings presented at a session of this title at the conference on "The Global North" convened in Stockholm in August 2019. In that session, the authors presented individual papers addressing the resource colonization of the Scandinavian inland from 500 to $1500 \mathrm{CE}$. For this special issue, we have chosen to integrate our individual contributions. Andreas Hennius is grateful for financial support from the Berit Wallenberg Foundation. Eva Svensson and Karl-Johan Lindholm have undertaken their research with support from the Swedish Research Council (VR 2017-01483). The authors are collectively grateful to conference organisers Kurt Villads Jensen and Emmy Atterving, and to the editor of this special collection, Carol Symes. In addition, we want to acknowledge two anonymous reviewers and express our gratitude for their constructive comments.
}

I Svensson and Gardiner, "Introduction."

2 See, for instance, Myrdal, Jordbruket under feodalismen, the second volume of Det svenska jordbrukets historia. 
example, recent studies have shown an intensified hunt for terrestrial mammals starting around the fourth century CE, followed by a subsequent exploitation of marine mammals in the following centuries. ${ }^{3}$ These developments are contemporary with indications of inland agricultural expansion during the late Roman Iron Age, extending along the main river valleys that connected the region with the Gulf of Bothnia in the east and the Atlantic in the west. ${ }^{4}$ At several places in the boreal forest, palynological studies suggest that agricultural settlements with permanent "field-and-meadow systems" were established during the early or middle part of the Iron Age, ${ }^{5}$ emerging along with the development of iron production. ${ }^{6}$ The settlement expansion of the Iron Age seem to have been mediated by an innovative set of developments consisting of livestock herding with shielings, small-scale cereal cultivation, and diversified outland use ${ }^{7}$ through which resources were transformed into commodities for trade and exchange. These activities shaped a diverse but fairly repetitive record of archaeological sites distributed outside historical villages and related to the use of forest resources such as game, fish, pasture, wood, sources of energy, rock, and minerals. ${ }^{8}$

Subsistence beyond the traditional spectrum of agriculture and animal husbandry is often considered a necessity when suitable land for cultivation is too scarce. In contrast, we argue that these valuable resources were the driving force behind an intensification of economic activity in this inland region. ${ }^{9}$ This intensification seems also to have contributed to far-reaching trade networks linking the Atlantic with the Baltic, as illustrated by the trade in whalebone gaming pieces which resulted in large volumes of standardized items being distributed across Scandinavia and the Baltic. ${ }^{10}$ Made from bones of the North Atlantic right whale (Eubalaena glacialis), these gaming pieces begin to appear in the sixth century and connect northern Scandinavia's coastal zones with eastern mid-

3 Ashby et al., "Urban Networks and Arctic Outlands"; Gustavsson et al., "Are Many Vendel and Viking Period Gaming Pieces?"; Hennius et al., "Whalebone Gaming Pieces"; Lindholm and Ljungkvist, "The Bear in the Grave."

4 Emanuelsson et al., Settlement, Shieling and Landscape; Magnusson and Segerström, "Leva i skogsbygd"; Ramqvist, "Fem Norrland"; Svensson, Människor i utmark.

5 Amundsen, ed., Elgfangst og bosetning; Karlsson et al., "The History"; Kvamme, "Pollen Analytical Studies"; Svensson, Människor i utmark.

6 0. Eriksson, "Origin and Development."

7 Emanuelsson, Settlement and Land-Use; Svensson, "Innovations in the Rural Edge"; Hennius, "Outland Exploitation."

8 For instance, Baug, Quarrying in Western Norway; Emanuelsson et al., Settlement, Shieling and Landscape; Hansson et al. Agrarkris och ödegårdar; Karlsson et al., "The History"; Loftsgarden, Marknadsplassar omkring Hardangervidda; Risbøl et al., eds., Kultur och natur; Rundberget, Jernets dunkle dimension; Stene, "Utmarka"; Stene, I randen av taigaen; Svensson, Människor i utmark; Svensson, The Medieval Household.

9 Lindholm et al., "Archaeology of the Commons"

10 Ashby et al., "Urban Networks and Arctic Outlands"; Gustavsson et al., "Vendel and Viking Period Gaming Pieces"; Hennius et al., "Whalebone Gaming Pieces"; Karlsson, Spill; Ljungkvist, "Continental Imports to Scandinavia"; Mikkelsen, Fangstprodukter i vikingetidens; Resi, "Reflections on Viking Age Local Trade." 
dle Sweden, the Åland Islands, and Denmark: all regions with a steady demand for raw materials. Whalebone remained the dominant raw material for manufacturing game pieces until the beginning of the eleventh century, when it was replaced by walrus tusks. Similar patterns have been noted for a variety of different goods. The trade in furs of the brown bear (Ursus arctos) developed in the Roman Iron Age, with the most intense phase dating from centuries before the Viking Age, and the archaeological remains of this trade are mainly associated with prominent burials in the agricultural regions of Scandinavia. ${ }^{11}$ Wild reindeer antlers from inland Scandinavia were used as raw materials for comb making in the Viking Age towns of Ribe, Aggersborg, and Århus (Denmark) and in the medieval towns of Norway. ${ }^{12}$

\section{Ecological Globalization}

Although connections between the exploitation of the outlands and the agricultural plains and coastal areas are archaeologically well established, the nature of these dynamic systems are still not fully understood. What was the main driver behind the technological and social innovations observable in the archaeological record and the development of trade networks? A recent study on the medieval trade in Greenlandic walrus has conceptualized similar patterns as "ecological globalization," a process by which the market for valuable natural resources results in the development of interdependencies between resource-extracting communities and distant centres of consumption. ${ }^{13}$ The research surveyed above suggests that ecological globalization was already underway in the Scandinavian inland region during the Iron Age, as shown by the intensified extraction of boreal forest resources and the establishment of far-reaching exchange networks. Most likely, this process also involved interdependencies between forest communities and people living in the central agricultural areas, but so far little is known about whether the people of the forested inlands adapted to external demands or if they took advantage of their surroundings in a more proactive way, in order to link their landscapes to the worlds outside.

Better known is that the boreal forests of inland Scandinavia constituted a heterogeneous ethno-linguistic environment. ${ }^{14}$ Over the course of the Iron Age and the medieval period, people were speaking different versions of the languages that became Sámi, Norwegian, Swedish, and Kvääni; from at least the late sixteenth-century there were also Finnish speakers. ${ }^{15}$ Hence, the ecological globalization of the boreal forests most likely fostered multilingual communities with overlapping identities, land-use systems, alli-

I I Lindholm and Ljungkvist, "The Bear in the Grave"; Petré, "Björnfällen i begravningsritualenstatusobjekt"; Zachrisson, "Vittnesbörd om pälshandel?"

12 Ashby et al., "Urban Networks and Arctic Outlands"; Rosvold, Hansen and Røed, "From Mountains to Towns."

13 Barrett et al., "Ecological Globalisation," 1. See also the article by Robyn Barrow in this collection.

14 Iversen, "Between Tribe and Kingdom," 250

15 Bergman and Edlund, "Birkarlar and Sámi"; Odner, Finner och Terfinner; Ramqvist, "Fem Norrland"; Welinder, Jämtarna och Samerna. 
ances, and crosscutting relations among families and households, presumably including levels of both cooperation and competition. From the sixteenth century onward, the development of nation-states resulted in the political construction of "fixed" ethnic identities and the drive for economic specialization, so that today the boreal forest is a contested landscape characterized by debates over its past.

For the purposes of the present article, a nuanced discussion of identity and ethnic affinity as evinced by archaeological materials is impossible. However, it can still be noted that the available evidence suggests that the Sámi people's transition from hunting and fishing to domesticated reindeer herding was initiated during the Late Iron Age. ${ }^{16}$ This change has been explained as resulting from the consolidation of Sámi communities in response to internal tensions at times of dramatic change, with the development of reindeer pastoralism as part of this process. In this period, as discussed below, we also see changes in the trading systems of the forested inland region, which in turn occurred simultaneously with increased indications of livestock herding, the origin of shieling systems, as well as tar and iron production. ${ }^{17}$ Our presumption is that these patterns were an effect of Iron Age ecological globalization, which resulted in the overexploitation of game (bear, moose, and wild reindeer), ${ }^{18}$ as well as the transformation of trade networks in relation to the Viking Age diaspora. ${ }^{19}$

\section{Research Objective and Overview}

The main objective of this article is to synthesize archaeological evidence pointing to processes of ecological globalization in forested inland Scandinavia during the time period ca. 500 to $1400 \mathrm{CE}$.

We argue that ecological globalization induced a process that can be conceptualized as "resource colonization" at the local level: that is, the increased exploitation of a surrounding landscape aimed at extracting valued products that could be transformed into commodities through crafts and trade. A crucial component of resource colonization is establishment of the means for communication and exchange. The first part of our empirical discussion therefore focuses on ways of reconstructing networks and contacts by analyzing information from burials. We begin with a distinctive burial tradition of the forested inland region which, in general, is contemporary with indications of increased exploitation of the boreal forests: the so-called hunting-ground or outland burials. These burials will be analyzed in relation to the communication network of landscapes and routes described in later Viking Age and medieval textual sources. We contend that these burials provide insights into local initiatives of hunting and craftsmanship, as well as to pre-Viking Age exchange networks crossing the inland forests and mountains.

16 Aronsson, "Pollen Evidence"; Bergman et al., "Kinship and Settlements"; Storli, "Sami Viking Age Pastoralism."

17 Hennius, "Viking Age Tar Production"; Lindholm et al., "The Archaeology of the Commons"; Loftsgarden, Marknadsplassar omkring Hardangervidda.

18 Lindholm and Ljungkvist, "The Bear in the Grave."

19 Jesch, The Viking Diaspora. 


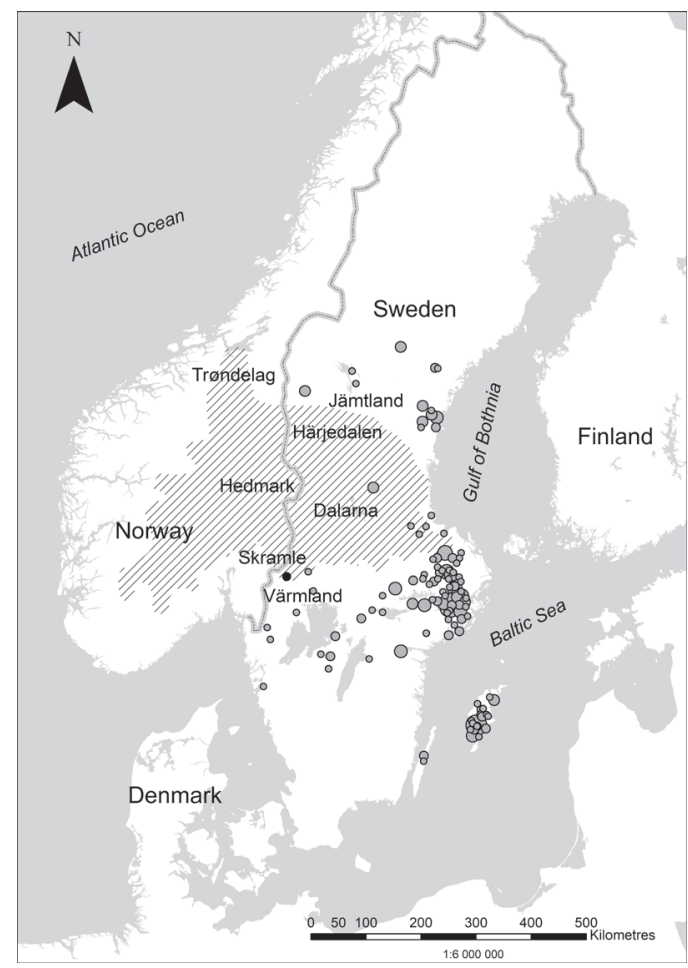

Map 2.1. Map of the Scandinavian Peninsula indicating the general area under discussion and the location of Iron Age burials containing bear phalanges.

Next, we discuss the main ideas behind our ongoing work of extracting and sequencing aDNA (ancient DNA) from remains of the brown bear. Many burials from the mid-Iron Age contain bear claws, which have been interpreted as the remains of entire furs or animals, since the claws were almost never used as pendants on their own. Moreover, in well-preserved inhumation graves, these claws are usually found in distinctive configurations representing each paw of the animal. Since these claws mainly appear in areas that were not suitable for bear habitats, the aim of our aDNA analysis is to determine the regions from which the bears or their hides were sourced: presumably the resource colonized landscapes of the boreal forests. Moreover, the bears' haplotypes-their genetic profiles-will help us to estimate the degree of their genetic diversity, which in turn may provide valuable insights into the human impact on Scandinavian bear populations due to over-hunting pressure during the Iron Age and the transformation of the boreal forests during the Viking Age.

The following part of our discussion will focus on the extraction of tar and iron, commodities that we argue to be especially useful for defining and understanding the changes brought about by resource colonization shortly before, during, and after the Viking Age. During the Viking Age, the scale of tar and iron production clearly grows, and this in turn seems to have been promoted by developments in coordination among communities, landscape reorganization, and advances in technology, seemingly reflect- 
ing inlanders' agency in meeting a greater demand for tar and iron. Up to the middle of the medieval period, production seems to have been mainly driven by the needs of the peasants living near these resources. In the twelfth century, however, it is possible to see an increased involvement of external actors in the Scandinavian inlands. The final part of this paper deals with the regression of the peasants' commodity production and their resistance to external involvement in resource extraction. To conclude, we will discuss some characteristic traits of the landscapes formed by resource colonization, especially the long-term continuity of these landscapes and their dynamic and multifunctional nature: qualities that indicate the presence of well-organized local communities that were able to take advantage of their forest resources.

\section{Outland Burials and the Landscape as a Communicative Tool}

Before the emergence of centralized emporia in the late Iron Age, interregional trade seems to have been organized and maintained by rather decentralized networks of exchange. ${ }^{20}$ Since trade resources were crucial for generating wealth, social status, and political influence, control of such communication routes was essential. ${ }^{21}$ Especially important were places in the landscape where several communication routes converged. In the central agricultural regions of Scandinavia, an apparent feature of such spaces are concentrations of burials; many of the places that later became central to trade often emerged in such areas. ${ }^{22}$

Hunting-ground or outland graves comprise low, round, stone settings which are morphologically very similar-although with a distinct boreal flavour-to contemporary Iron Age graves located in the central agrarian areas of Scandinavia during the first millennium CE. The main difference is that the burials are not located near a farmstead or a village, but in outland areas characterized by dense forests or mountains. Excavations of outland graves have often revealed unusually rich grave goods, especially from burials dated to the late Iron Age (600-1050 CE). These objects include spears and arrowheads, iron tools like hammers and chisels, and jewellery in the form of beads and bronze belt buckles. ${ }^{23}$ These materials link the burials with craft centres located outside the forested inland region. ${ }^{24}$ Outland graves are mainly found in the regions of Dalarna, Härjedalen, and Jämtland in Sweden; and in the regions of Hedmark and Dalarna in Norway. ${ }^{25}$ Roughly, they can be divided into two phases. In the early Iron Age (200 BCE-600 $\mathrm{CE}$ ), they were often arranged in groups, with up to forty graves in the same place. In the late Iron Age (600-1100 CE), outland graves were more commonly constructed in solitude or in smaller groups of two to five.

20 Helgesson, Järnålderns Skåne; Welinder, Jämtarna och Samerna. On the emergence of these emporia, see the article by Natalja Grigorjeva in this volume.

2 I Ramqvist, "Utbytessystem under det första."

22 Andrén, "Från antiken till antiken."

23 Serning, Dalarnas järnålder; Wehlin, "Fångstmarkens folk."

24 Christensen, "Reinjeger og kammaker"; Lindholm and Ljungkvist, "The Bear in the Grave."

25 Gollwitzer, "Yngre järnålder i fjälltrakterna." 


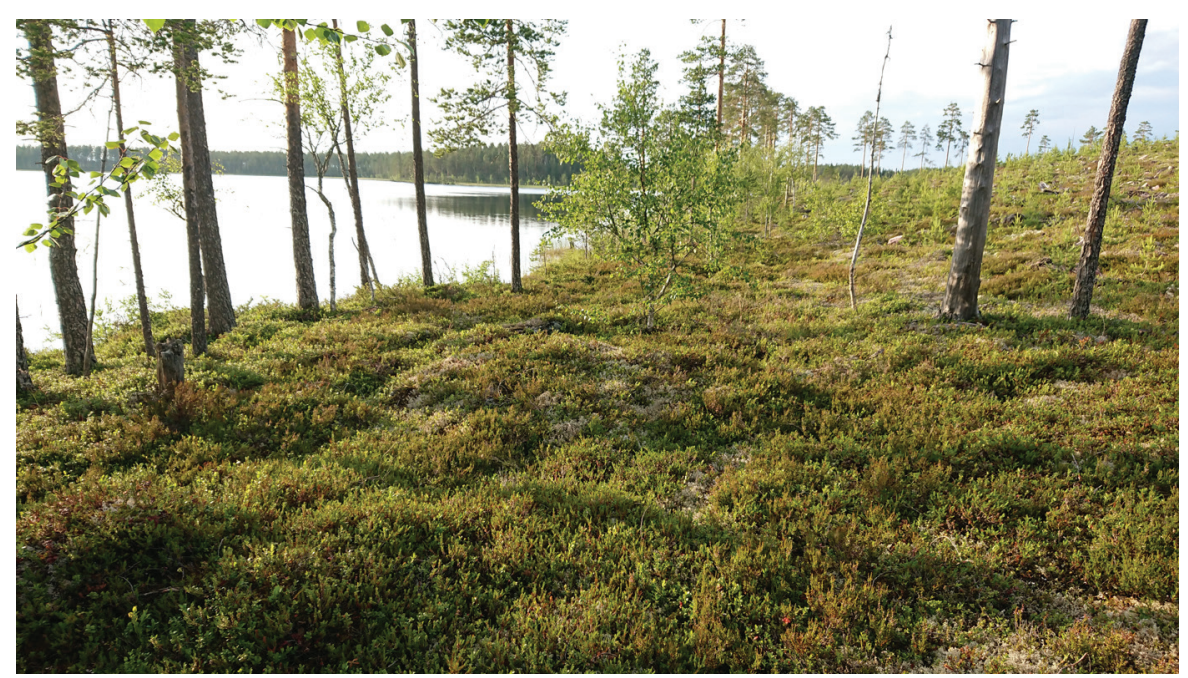

Plate 2.1. Graves and archaeological remains in outland areas are often very hard to see. The solitary grave mound in the central part of the picture above is only revealed by the small change in elevation and a slight change in vegetation, in the form of white moss growing on the stones (Horrmunden, Dalarna, 600-700 CE).

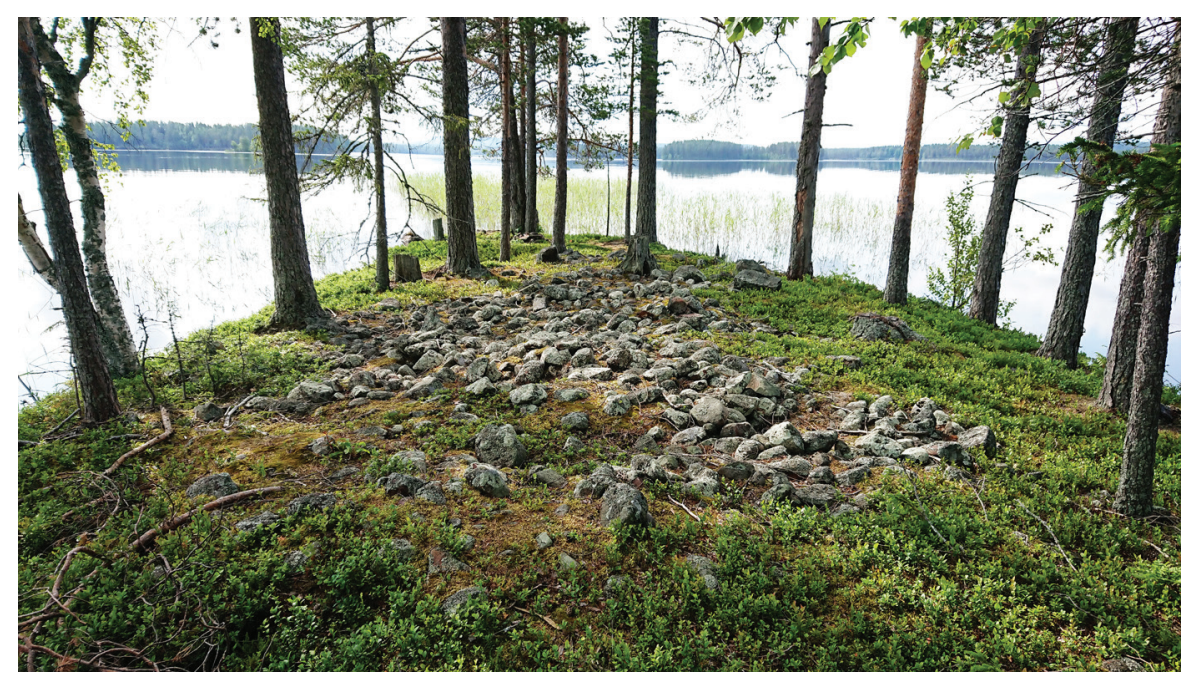

Plate 2.2. Grave field on a small promontory in the lake of Horrmunden, Dalarna, Sweden. The site has not been excavated, but the location and character of the site indicates an early Iron Age date. 
Unfortunately, few settlements contemporary to these burials have been identified in the inland region, which makes it difficult to contextualize them. However, they occupy the same geographical settings as other archaeological sites that are more visible in the landscape, for example the wide-ranging pitfall trap systems used for hunting wild reindeer and moose (see below). ${ }^{26}$ Outland graves were first scientifically described in the 1930s, and since then archaeologists have debated whether the communities constructing the graves were colonists from agrarian areas or a pre-existing population which subsisted on hunting, fishing, and gathering; the latter viewpoint is dominant today. ${ }^{27}$ However, a strict dichotomy between farming and hunting/gathering communities is problematic; based on archaeological investigations and pollen analysis from the burials, it has been suggested that the hunting and gathering communities in the forested region also practiced animal husbandry to some extent, in some cases as early as the late Bronze Age (ca. 1700-500 BCE). ${ }^{28}$

A spatial analysis of outland burials from Dalarna and Hedmark indicates that the burials' early phase is concentrated in low-lying forested areas. Furthermore, the graves are often placed near rivers and lakes: 82 percent of the thirty-four graves in the lowlying areas (defined as below seven hundred metres above sea level) which have been studied are located within one hundred metres from a larger lake or river. ${ }^{29}$ Transport on watercourses was likely the preferred means of travelling, both during the summer and in the wintertime. Moreover, many of the burials are located on narrow promontories where they would have been visible from all directions. One of the exceptions is the grave at Vidjesundsfjärden, Dalarna, which is located in a small bay with limited visibility from the surrounding area. Its location near the shore may signify its important symbolic role in the burial ritual, perhaps as a boundary between the living world and afterlife. But the general pattern of exposed locations is arguably as significant for understanding the function of these burials as landmarks within communication networks.

A similar pattern can be noted for the burials of the later phase, which in general are concentrated in the elevated mountainous terrain at altitudes from about seven to eleven hundred metres above sea level. ${ }^{30}$ Previous research has suggested that these mountain graves were not placed randomly in the landscape; rather, they were constructed at exposed positions in connection to trade routes. ${ }^{31}$ An additional argument for relating these burials to communication networks can be made by comparing the distribution of the outland burials in both Hedmark and Dalarna with the medieval pilgrimage route to the shrine of St. Olof at Nidaros (modern day Trondheim in Norway).

This route appears in written accounts from the twelfth century onward, but its spatial relationship with outland burials makes it likely that it was based on an older,

26 Lindgren, Mötesplatser i fängstmarken.

27 See for example Bergstøl, Samer i Østerdalen; Bolin, "Två undersökta gravfält"; Hougen, Fra seter til gård; Inger Zachrisson Möten i gränsland; Stig Welinder Jämtarna och Samerna.

28 Wehlin, "Fäbodarnas historia."

29 Lindgren, Mötesplatser i fängstmarken.

30 Skjølsvold "Refleksjoner omkring jernaldersgravene."

3 I Skjølsvold "En fangstmanns grav." 


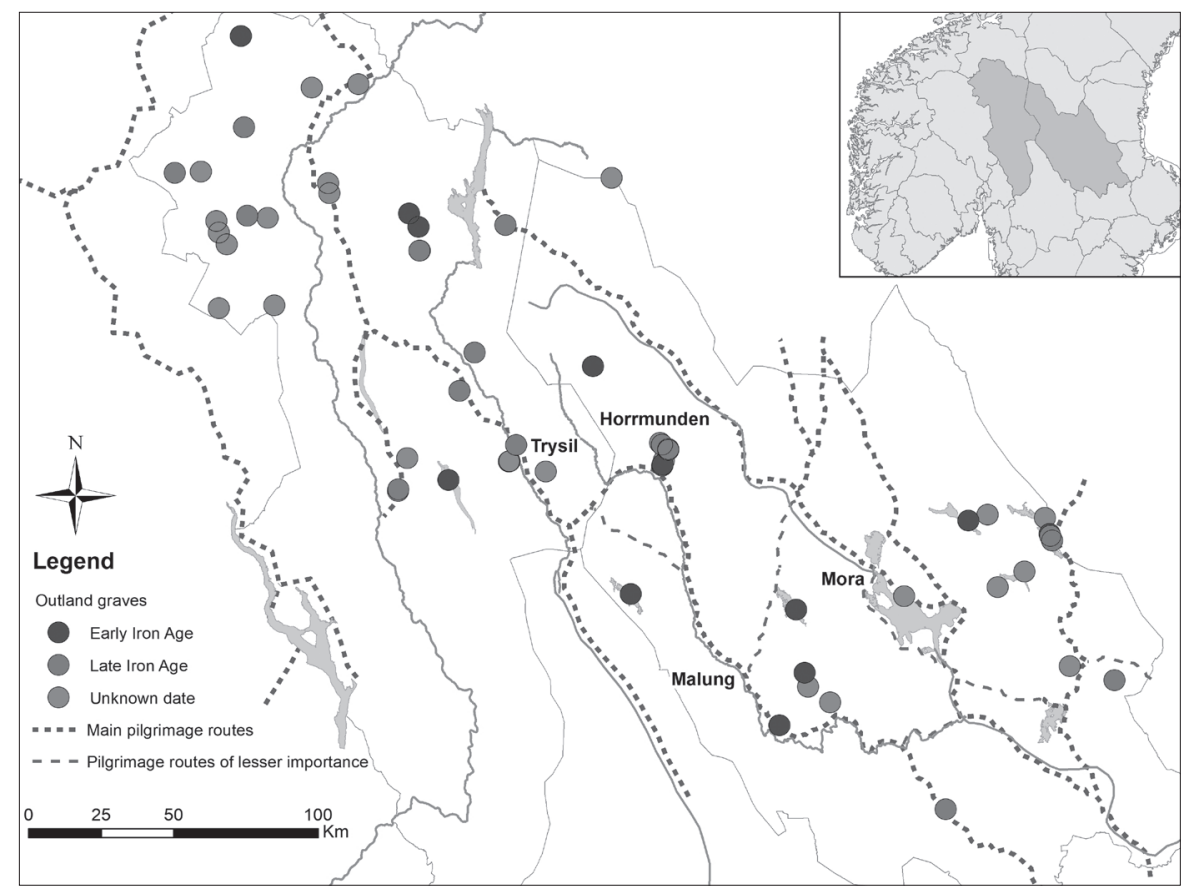

Map 2.2. Known outland graves in Dalarna and Hedmark and their relation to travel routes and main river systems. The map is based on traditional pilgrimage routes to Nidaros (Trondheim, Norway) and maps from the seventeenth century. Reproduced with permission.

pre-existing path whose origins may go back to the Iron Age. This single example demonstrates the potential for reconstructing the past route systems of the Scandinavian inland region.

The material culture of the outland burials and their placement in the landscape are both important for reconstructing contacts and communication in inland Scandinavia. Some of the burial sites reveal continuous use over several hundreds of years, for example the grave fields around lake Horrmunden in Dalarna, Sweden, and the graves at Lilla Solensjøen in Hedmark, Norway. These places are also located in convergence zones of different river networks and in boundary locations between lowland and highland regions. ${ }^{32}$ These locations and their longevity can be seen as indications of their function as meeting places and hubs for trade and communication. Indeed, the importance of trade between western Dalarna and Norway is also known from written sources. ${ }^{33}$ Other findings suggest that iron ore artifacts were deposited in the ground there during a time when there was an increase in the construction of trapping pit, or pitfall, systems in Jämtland. This may well reflect changes in the organization of the surrounding com-

32 Hyenstrand, "Forntid i gränsland."

33 Hyenstrand, "Forntid i gränsland"; Ljung, Sankt Olofi Dalarna. 
munity to intensify hunting. But further investigations are needed in order to confirm the established patterns and to further our understanding of the networks that linked the inland with the worlds outside.

\section{Tracing Trade through the Ancient DNA of Brown Bears}

DNA extracted from old biological remains contains information on the individual organism, as well its broader population and species. With the latest technology, even highly degraded materials can yield sequences of both mitochondrial (mtDNA) and nuclear DNA. ${ }^{34}$ Even though this research has focused primarily on humans, these methods are increasingly applied to other animal species, both wild and domesticated, as well as to bacteria. ${ }^{35}$ Most often, aDNA has been used to study phylogeography and demographic processes. However, by assigning individuals to a genetic type or group, the method can also be a tool for estimating provenance within a certain geographical region. ${ }^{36}$ This application of aDNA is quite recent, but has a significant potential to answer both ecological as well as archaeological questions.

A key question for us concerns how humans have affected wild animal populations through harvesting and trade. ${ }^{37}$ In two recent studies, this approach has been successfully applied to food remains and artifacts traded over long distances during the Viking Age; by assigning haplotypes geographically, it was possible to estimate the region of origin for traded codfish and walrus ivory. For the walrus material, a mitochondrial haplotype exclusively found around Greenland and eastern Canada was used to trace long distance trade from the Norse colony on Greenland to northern Europe. ${ }^{38}$ An important prerequisite for successfully assigning genetic types to a certain geography is a distinct population structure, preferably delineated by using DNA from contemporary samples. ${ }^{39}$

One species that has a strong geographic structure based on the mtDNA, and is therefore particularly well suited for studies of geographical provenance, is the Scandinavian brown bear (Ursus arctos). A distinct latitudinal division between a northern and a southern group characterizes its DNA and the two populations meet at a contact zone located in the central Scandinavian Peninsula, in the regions of northern Trøndelag (Norway) and northern Jämtland (Sweden). ${ }^{40}$ Since females exclusively pass on mtDNA, this structure is believed to be maintained due to female bears not dispersing far from their mother's home range. ${ }^{41}$ Despite a recent "demographic bottleneck" in the bear

34 Hofreiter et al., "Future of Ancient DNA."

35 Brunson and Reich, "Promise of Paleogenomics."

36 Arndt et al., "Roman Trade"; Hartnup et al., "Ancient DNA."

37 See also Gifford-Gonzalez, "New Ecological Directions," for additional applications.

38 Star et al., "Ancient DNA of Walrus Ivory"; Star et al., "Ancient DNA of Viking Age Cod."

39 Rosvold et al., "From Mountains to Towns."

40 Taberlet and Bouvet, "Localization of a Contact Zone."

4 I Støen et al., "Inversely Density-Dependent Natal Dispersal." 
population, the structure seems to have remained intact over the last centuries and is most likely of ancient origin. ${ }^{42}$

For humans of this region, the brown bear is intimately associated with the boreal forest and has played a prominent role in Scandinavian cultures. Among the Sámi, it is one of the most significant animals and numerous rituals and taboos have characterized their relationship with it. ${ }^{43}$ Notably, the bear was venerated as a sacred creature and, after consumption of the flesh, the bones were arranged in anatomical order and buried in so-called bear burials. ${ }^{44}$ In Norse culture, bears are featured in myths and legends and (as already noted) remains of the animal are frequently found in graves, especially during the mid-Iron Age. ${ }^{45}$ The remaining claws are assumed to originate from furs which covered or supported the deceased. These graves are commonly found in Scandinavia's central agricultural region, and since bears were likely scarce or completely absent in those areas, the remains of their furs potentially indicate the existence of far-reaching trade networks.

Indeed, a significant increase in the occurrence of these bear claws around the sixth and seventh centuries coincides with traces of peaking trade activity in the Scandinavian inland. A recent study shows intensified pitfall trap construction beginning as early as the Bronze Age, but with increased intensification from the end of the Roman Iron Age (ca. 300-400 CE) to the beginning of the Viking Age. The first peak appears in the Vendel period (550-790 CE), several hundred years earlier than previously assumed, and at the same time when bear furs were deposited in large numbers in burials of the central agricultural regions. Although bears were probably not hunted in pitfalls, this revised chronology shows a general increase in the exploitation of terrestrial animals in the middle of the Iron Age and no direct connection to a presumed expansion in the Viking Age. The increase in the use of pitfall traps, as well as the discovery of numerous hordes of Roman coins, attest to intensified hunting and far-reaching networks, presumably through middlemen, trading with Roman colonies. ${ }^{46}$ Interestingly, these pitfall trapping systems are most densely distributed in Jämtland, geographically overlapping with the contact zone between the two mtDNA-groups of bears.

The geographic origin of the bear furs from the Iron Age graves in southern Scandinavia could thus potentially reveal not only an important connection to the forested region of inland Scandinavia, but also to other areas of the global North, providing a unique insight into the provenance of the bears as resources for hunting and trade. Genetic data from prehistoric brown bears has been collected and is currently being used to build a genetic reference map. The sampled bear remains were collected from graves in central and southern Scandinavia, as well as from northern Sweden and the inland regions. We have especially targeted datable remains from Sámi bear burials,

42 Xenikoudakis et al., "Consequences."

43 Rydving, "'Bear Ceremonial'”

44 Zachrisson and Iregren, Lappish Bear Graves.

45 Petré, "Björnfällen."

46 Lindholm and Ljungkvist, "The Bear in the Grave”; Zachrisson,"Vittnesbörd om pälshandel?" 
sacrificial sites, and human burials capturing a range of cultural contexts. We are thus hopeful that, by using specifically adapted techniques to extract and sequence the DNA, ${ }^{47}$ we will be able to determine the geographical origins of the bears. In addition, their haplotypes will enable an estimate of their genetic diversity, which can indicate how intensified human hunting affected the Scandinavian bear population; the geographical distribution of the two mtDNA-groups will be viewed in relation to the proposed resource colonization processes of inland Scandinavia. At this time, based on data from burials located in the central agricultural regions, a considerable decrease in bear furs can be noted in the Viking Age, suggesting over-exploitation that is reflected in the chronology of pitfall systems. ${ }^{48}$ It is also possible to identify a contemporary transformation in the land-use systems of boreal forests, especially in the production of tar and iron.

\section{Forests in Transformation:Viking Age Tar Production}

Up to the beginning of the nineteenth century, tar produced in kilns or dales was one of the major export commodities of Sweden (then including Finland). The production dominated the international market and was fundamental for maintaining European fleets of wooden ships. ${ }^{49}$ (Tar has been used for a number of different purposes, but the most important function has been the treatment, protection and sealing of wooden constructions. $)^{50}$ The method for obtaining tar is to heat green wood in a low-oxygen environment; in Scandinavia, the most commonly used wood is pine. Although the use of resinous products has a very long history, reaching as far back as the Palaeolithic era, ${ }^{51}$ prehistoric tar production has received little archaeological attention until recently.

In Sweden, ancient funnel-shaped tar production pits were first detected by archaeological research in the province of Uppland..$^{52}$ Because these facilities lack the drawing pipes known from historically described tar dales, they have accordingly been interpreted as remains from a different and older, direct method of tar production. This interpretation has been supported by a combination of archaeological observations, analogies to central European findings, and geochemical analysis. The chronology of the funnels shows an initial phase of construction dating to the Roman Iron Age, characterized by small-scale household production organized at the settlement level. In the late Iron Age, evidence suggests the development of large-scale tar production, marked by a geographical shift in production from settlements to the forested outlands. The change in location also involved a change in size and scale: whereas production in the settlements was based on funnels about a metre in diameter, capable of producing around fifteen litres of tar in every cycle, the outland funnels extended up to ten metres in diameter with an estimated production of around three hundred litres in one production cycle.

47 Ersmark et al., "Genetic Turnovers."

48 Hennius, "Towards a Refined Chronology."

49 Villstrand, "En räddande eld."

50 Persson, Jag väntar vid min mila.

5 I Schmidt et al., "Birch Tar Production."

52 Hennius, "Viking Age Tar Production." 
Even if it were possible to produce larger amounts of tar through repeated firings in smaller pits, the transition to forest production suggests a major increase in demand contemporary with the emergence of the Viking Age's intensified maritime culture. Experiments have shown that a single Viking ship required approximately five hundred litres of tar that had to be maintained by repeated coatings. Furthermore, the treatment of sails made from wool also required large quantities of tar, mixed with grease, in order to avoid excess permeability. There are also contemporary indications that tar was becoming a major commodity at emporia around the Baltic. Brushes and buckets found at both Hedeby and Birka indicate the handling and use of tar; at Ribe and Schleswig, finds of containers are evidence for long-distance transports of tar from the early eighth century and onwards. ${ }^{53}$

The exponential transformation of medieval tar production was almost certainly driven by economic forces as well as a series of societal changes. More important, however, for our purposes, is the fact that the strategic transition to a location near to the raw materials implies a completely different way of organizing production, including long-term planning and forest management. The scale of production means that large numbers of people had to be released from their ordinary tasks in agrarian settlements in order to spend time at tar production, which involved the intense labour of cutting and splitting trees, the construction and maintenance of funnels, the piling of wood, oversight of the extraction process, and finally the transport of several hundred litres of tar to the trade or construction site. There are indications that some of the tar production sites in the later medieval and post-medieval periods evolved into shielings (seasonal settlements) and it could be suggested that these sites were used seasonally, perhaps in combination with livestock herding. ${ }^{54}$

\section{Steady Supplies of Iron}

Increased tar production is not the only evidence for the intensified resource colonization that transformed the boreal forest landscapes of the later Iron Age and early Middle Ages. ${ }^{55}$ For the last two millennia, iron has been among the most important of resources, needed for agricultural tools, construction, and weapons. A stable and steady supply of iron produced in these inland regions was therefore vital to the central role Scandinavia played in the economy of the Late Iron Age. The iron was produced from bog ore, while the large woodland areas provided plenty of fuel for bloomery furnaces. Thousands of iron production sites are known, and it is likely that this is still just a fraction of the total number of sites that would once have existed. Production became increasingly prevalent from around 500 to 400 BCE. ${ }^{56}$ In this first phase, slag was solidified in a pit below the shaft furnace, with the consequence being that the furnace needed to be rebuilt after

53 Hennius, "Viking Age Tar Production."

54 Hennius, "Viking Age Tar Production."

55 Magnusson, Lågteknisk järnframställning.

56 Hjärthner-Holdaret al., "Blästbruk"; Stenvik, Iron Production. 


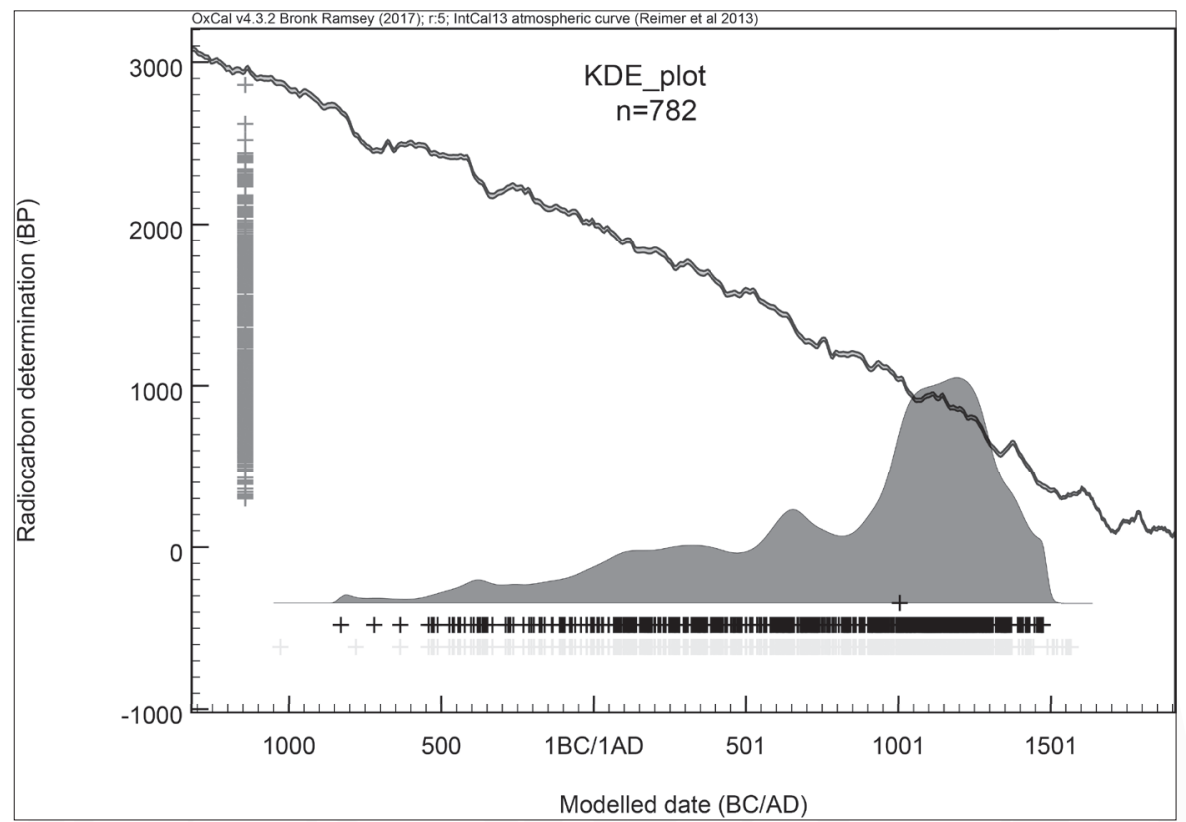

Figure 2.1. A kernel density estimated distribution (KDE) of radiocarbon dates ( $\mathrm{n}=782)$ from iron production sites (excluding charcoal pits) in southern Norway. The dates are analysed in OxCal v3.4.2. (Ramsey, Methods for Summarizing Radiocarbon Datasets.) Reproduced with permission.

each smelt. ${ }^{57}$ However, this method was effective provided that production was well organized and could draw on sufficient labour. ${ }^{58}$

From around $600 \mathrm{CE}$, there was a gradual change in technology from labour-intensive large-scale sites to smaller sites with reusable furnaces. ${ }^{59}$ Charcoal was now produced outside the furnace, and this expanded the species of wood that could be used as fuel, including mountain birch, and opened up large, high-lying areas for iron production. ${ }^{60}$ This change in technology facilitated an integration of iron production alongside the agrarian activities of husbandry and small-scale cereal cultivation. From this time onwards, iron production in Scandinavia was increasingly concentrated in the inland and woodland areas (see Map 2.3). Most sites were quite small, with one or two bloomery furnaces in which the reduction of ore could have been done in just a few days. However, preparations before the actual smelting were more time consuming, involving the collecting, drying, and roasting of the bog ore, forest clearing, and the production of charcoal, before finally collecting clay and building the furnace. The need for careful organization

57 Lyngstrøm, "Slaggeaftapningsovne"; Stenvik, Iron Production.

58 Myhre, "Landbruk."

59 Larsen, Jernvinneundersøkelser; Rundberget et al., Ovnstopologi og Ovnskronologi.

60 Loftsgarden, "Kolgroper." 


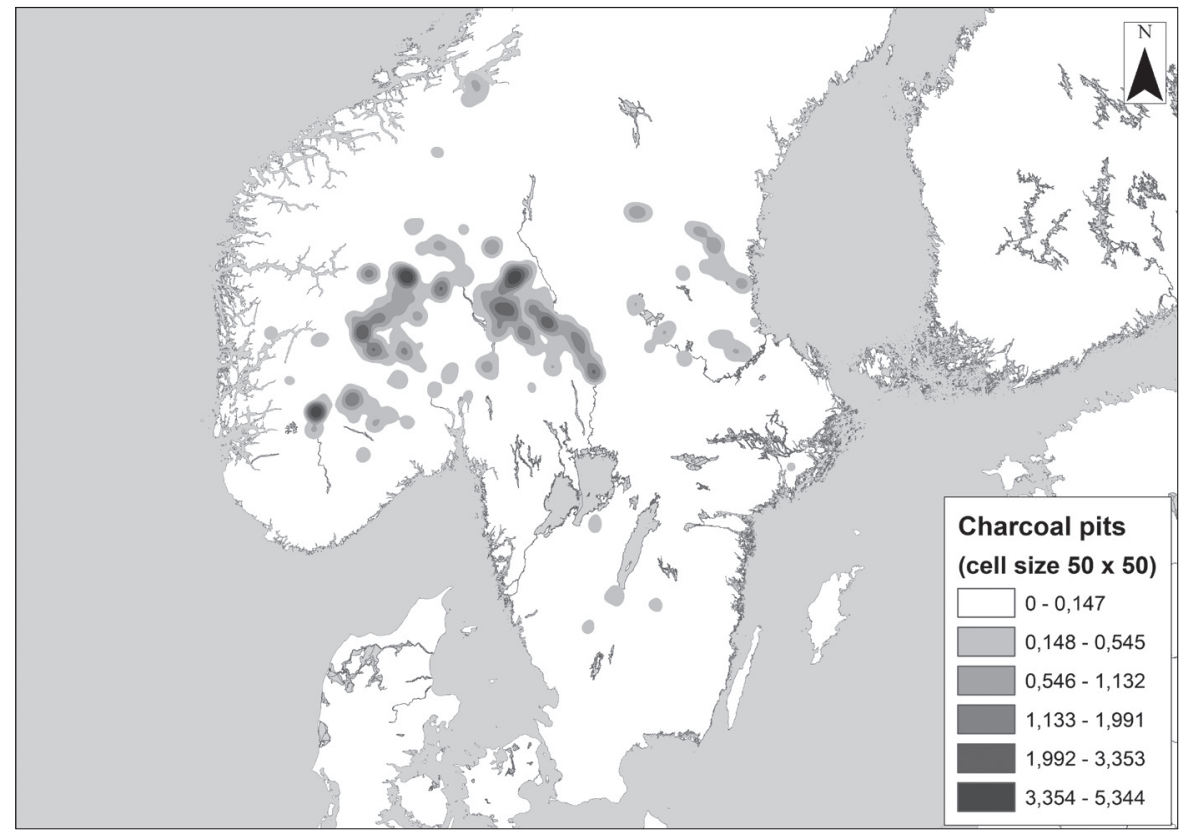

Map 2.3. Kernel density map showing the distribution of known charcoal pits $(32,668)$. Charcoal pits are closely connected to iron production in the Viking and Middle Ages.

In contrast to iron production sites, which are difficult to detect, the charcoal pits are still quite visible in the landscape. The spatial distribution of charcoal pits can hence provide a more representative spatial overview of the core areas of iron production in this period.

Data from the Norwegian database for cultural heritage (Askeladden) and the

Swedish National Heritage Board's database for archaeological sites and monuments (Fornsök). Map by K. Loftsgarden. Reproduced with permission.

as well as the number of extant sites suggests that iron production had become an integral part of the forest's agrarian landscapes and the lives of the people living there. ${ }^{61}$

Based on metallurgical analyses, one can estimate the ratio between the amount of slag on a given site and the amount of iron produced there. ${ }^{62}$ In turn, extrapolation from well-surveyed regions allow estimates of the total number of iron production sites that flourished from the Viking and Middle Ages. Multiplying this estimate by the average amount of slag on each site, it is also possible to estimate the total amount of iron produced in these eras. That estimate points to the production of about sixty thousand tonnes of iron from the Hardangervidda region and its surroundings in southern Norway, and about one hundred and ninety thousand tonnes throughout the whole of southern Norway. ${ }^{63}$ As shown in Figure 2.1, and highlighted above, there was an espe-

6 I Loftsgarden, Prime Movers.

62 Englund, Blästbruk, 288-91; Rundberget, Jernets dunkle dimensjon, 250.

63 Rundberget, Jernets dunkle dimensjon, 253-54; Loftsgarden, Marknadsplassar omkring Hardangervidda, 69. 
cially high production rate in the period $950-1300 \mathrm{CE} .{ }^{64}$ These estimates indicate that iron production in this region exceeded both local and regional demand, which in turn indicates that inland farmers did not primarily produce iron for local consumption, but for trade and exchange. ${ }^{65}$

Three factors contributed to this massive expansion of iron production from the end of the Viking Age: new technology, increased demand for iron, and the existence of stable economic networks and places of trade. As noted above, the introduction of charcoal pits expanded the varieties of wood that could be used as furnace fuel, including mountain birch. ${ }^{66}$ In addition, production sites became smaller and less labour-intensive. This meant that production became more flexible and could be adapted as a component to any multi-use farm, alongside livestock herding, small scale agriculture, fishing, hunting, and trapping. ${ }^{67}$ However, an iron production technology suited for skilled inland farmers is irrelevant if they cannot exchange the iron, leading us to the second factor: increased demand. The rise of regional surplus production can thus be seen as a result of supply and demand mechanisms affecting the value of iron, although caution is required when applying modern economic concepts to premodern conditions. ${ }^{68}$

One important driver was population growth from the Viking and Middle Ages, ${ }^{69}$ which in turn was linked to the introduction of scythes, iron-shod spades and more effective plows that improved agricultural yields. ${ }^{70}$ A larger population then further increased the need for iron tools, weapons, and building materials, most likely increasing the value of iron as a resource and a commodity. The expansion of iron production to inland areas suggests that farmers there considered the benefit sufficient for the risk of diverting already scarce resources, such as time and labour, on surplus iron production. A final determining factor for the emergence of regional surplus production was stable economic networks and secure places for trade and exchange. If farmers embarked on extensive iron production, they had to prioritize this work over other ventures with potentially more secure returns. Therefore, they had to be sure that they could trade their surplus iron, which presupposes stable societal structures that allowed trading networks and annual or permanent marketplaces to be maintained over extended periods. ${ }^{71}$

64 Larsen, Jernvinneundersøkelser, 181-83.

65 Loftsgarden, Marknadsplassar omkring Hardangervidda, 69-72.

66 Loftsgarden, "Kolgroper."

67 Tveiten and Loftsgarden, "Extensive Iron Production."

68 Loftsgarden, Mass Production; Skre, Monetary Practices.

69 Lunden, Norge under Sverreætten, 261-62.

70 Myrdal, Jordbruket under feodalismen; White, Medieval Technology, 53; Eriksson, "Origin and Development."

7I Loftsgarden, Mass Production. 


\section{“The Last Battle": Defending Commodity Production and Trade Networks}

In 1921, a mass grave was discovered in Stora Tuna, Dalarna (Sweden). Recent osteological analyses show that the buried persons had been executed by decapitation with an axe or sword. The event has been dated to the twelfth century, ${ }^{72}$ which implies that the mass grave is contemporary to a period of growing control of trade hubs and emerging urban centres by royal, ecclesiastical, and aristocratic powers. ${ }^{73}$ This societal and political development challenged the claims of self-organization and independence maintained by the landed peasants of inland Scandinavia. Not least, the royal demand for increased control of trade posed a threat to the forest agrarian peasants relying on commodity production and trade for their wealth and status. In addition, technological innovations created new competitors for the commodities produced in the outland. The invention of blast furnaces in the Swedish mining district competed with small-scale iron production, while an evident switch from the use of antlers to bones from butchered livestock, as seen in remains from comb-makers' shops, reduced the demand for commodities produced by forest peasants. ${ }^{74}$

In the twelfth and thirteenth centuries, then, local commodity production and peasant-controlled trade networks seem to have been under severe threat. But the question remains: did the forest peasants accept the developments without a fight, or did they manage to resist? We do not know if the mass grave in Stora Tuna was the result of a vanquished peasant uprising. What we do know is that these findings are contemporaneous, and that forest peasants in the region pursued outland commodity production that generated wealth. Resistance need not have been armed, but could have been enacted in many other ways. ${ }^{75}$ In order to shed light on what the archaeological record can tell us about peasant resistance in defence of their outland commodity production, we will move from Dalarna to the adjacent region of northern Värmland. ${ }^{76}$

In northern Värmland, forest peasants had produced bloomery iron at least since the sixth century CE, but from the ninth century onward this practice was transformed to surplus production in combination with more intensified hunting by pitfall systems, as described above. Judging from the spatial organization of Viking Age and medieval sites, the hamlet seems to have been the main production unit for both iron production and pitfall hunting. However, in the early thirteenth century, we see a clear break, first in the production of iron and then, some fifty years later, in pitfall construction and elk hunting. The downturn is radical, and production apparently dwindled to nearly nothing. Then, in the fourteenth century, iron production increases slightly, based on the introduction of new modes of organization and improved technology. At iron produc-

72 Wehlin et al., "Avrättningar och centralmakt."

73 See, for example, Lindkvist and Ågren, Sveriges medeltid.

74 Pettersson Jensen, Norberg och järnet; Vretemark, Från ben till boskap.

75 For instance, Scott, Decoding Subaltern Politics.

76 The following description is based on Emanuelsson et al., Settlement, Shieling and Landscape; Svensson, Människor i utmark, and Svensson, The Medieval Household. 


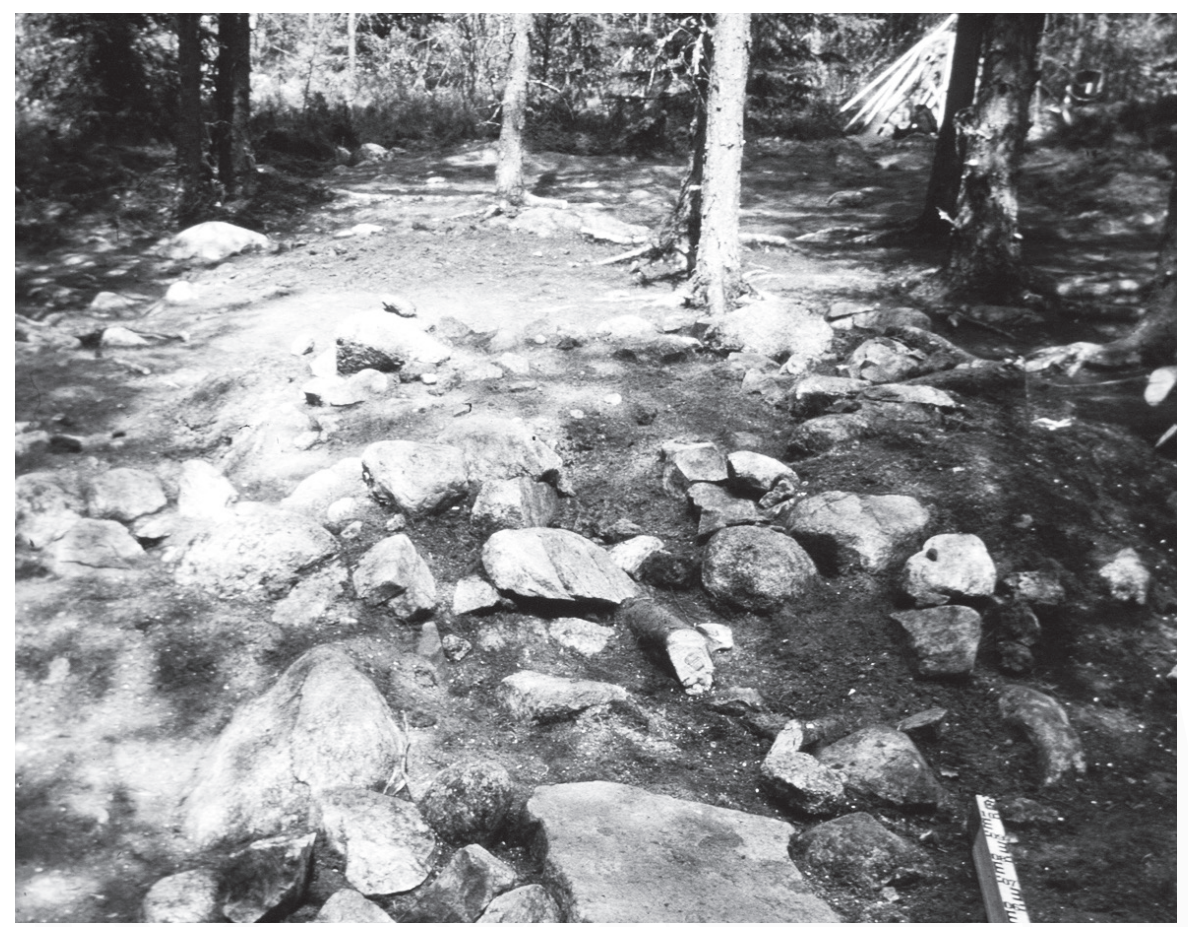

Figure 2.2. The furnace during excavation at the bloomery iron production site of Lillbergsgården, Northern Värmland, dated to the fourteenth century. Photo: Eva Svensson. Reproduced with permission.

tion sites, new, more stable, and probably larger furnaces, likely borrowing some traits from the new blast furnaces, were constructed: see Figure 2.2. The work of cleaning the bloom, previously performed at the different farmsteads, was now conducted at the iron production site, which saved both labour and transport. The production of charcoal was also reformed, probably by introducing charcoal stacks similar to blast furnace technology. ${ }^{77}$ Another novelty was the introduction of a water-powered smithy, which probably operated on a communal level, in contrast to the smithing previously carried out at individual farmsteads or hamlets. New organizational forms based on increased cooperation are also visible in the pitfall hunting systems of this time, as we have already noted, involving the collective ingenuity and labour of several farmsteads and hamlets. When intense pitfall hunting took off in the ninth century, single or several grouped pitfalls became standard, again to be replaced in the fourteenth century by long systems of pitfalls for elk that involved cooperation on a large scale.

What do these changes signify? In a time of emerging crisis, involving the threats of authoritative powers and new technologies competing with forest peasants' com-

77 There has been no systematic survey of charcoal stacks in the area, therefore this is a qualified guess based on the recording of a few sites. 


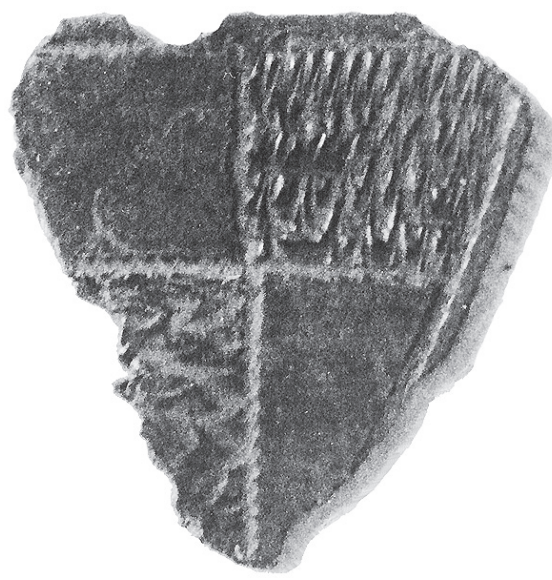

Figure 2.3. The "heraldic" mount from Skramle. Photo: Bengt Holte. Reproduced with permission.

modity production, local peasants seem to have chosen to draw on older, more cooperative forms of land management. Renewed cooperation and the reestablishment of collective resources aimed not only to be more competitive in commodity production, but was also a form of resistance against the increasing external and hierarchical powers of crown, clergy, and the nobility. The resistance also seems to have included direct chal-

lenges to the nobility. The aristocracy sprang, in most cases, from families with considerable wealth, social status, and capacity for conspicuous consumption. The aristocracy invested in symbols, such as coats of arms, to visualize their identity and status as noble lineages. ${ }^{78}$ Yet the landed forest peasants also owned such resources, especially those from families who had been involved in commodity production and trade for long periods of time. From excavated settlements there is evidence of these peasants possessing horses, weapons, and imported goods. Retrieved accessories indicate that the peasants were also aware of aristocratic fashion and dress codes. They even responded in kind to the introduction of noble symbols, as shown by the thirteenth-century heraldic mount with a homemade coat of arms found in an excavation at the hamlet of Skramle. ${ }^{79}$

The efforts of the forest peasants failed, however. The improvement of production technologies and increased cooperation to meet the competition of the emerging nobility was not enough. Markets for peasant outland commodities disappeared, and instead the forest peasants focused on the agrarian side of their economy, especially livestock herding and cattle breeding. During the later Middle Ages, the use of shielings grew significantly and, in the early modern period, shielings became a new platform for forest commodity production, fulfilling demands from the expanding Swedish mining districts. Thus, with the loss of their trade networks, the forest agrarian peasants became more closely aligned with what the word "peasant" means today. The archaeological sites, and possibly the decapitated bodies in the mass grave of Stora Tuna, can be understood as memorials of a battle that has not been recorded in written documents, and thus not properly told before.

78 Duggan, Nobles and Nobility.

79 Andersson and Svensson, Skramle; Svensson, The Medieval Household. 


\section{The Resource-Colonized Landscapes of the Global North}

During the first fifteen hundred years of our era, Scandinavian societies became increasingly integrated into global politics and economies. Networks for interregional contact and flows of trade goods were formed and an increased array of imports-from Europe and from the forested outlands of Scandinavia's inland region-accumulated in the central marketplaces that emerged during this period. In this article, we have presented ongoing archaeological research into Scandinavia's forested inland region, proposing that its people and communities were socially and economically integrated into systems of trade and in close interaction with the worlds outside. At the local level, this process resulted in intensive resource colonization that shaped landscapes and aimed the exploitation of valued resources for crafts and trade. An apparent feature of archaeological sites in the forested landscapes is that they appear in clusters which are not randomly distributed. ${ }^{80}$ These clusters sustained sets of different activities over a longue durée: big game hunting, livestock herding, iron smelting, tar production, and the construction of routes and burial grounds which can be seen as significant for the development of communication networks. The long continuity of these managed landscapes was the result of locally driven enterprises that claimed multifunctional activity areas through collective action and organization, and were already established in the early or middle Iron Age. Their resource colonization by peripheral hunting and/or forest agrarian livestock-herding communities was consequently based on-and also determined by-complex social and economic relations reflecting interrelated socio-economic systems of extraction, production, and consumption. We argue, therefore, that resource colonization and commodity production in the forested inlands of Scandinavia are crucial to identifying and understanding the contours of the premodern global North.

80 Lindholm et al., "The Archaeology of the Commons." 


\section{Bibliography}

Amundsen, Tina, ed. Elgfangst og bosetning i Gråfjellområdet. Oslo: Kulturhistorisk museum, 2007.

Andersson, Sofia and Eva Svensson, eds. Skramle-The True Story of a Deserted Medieval Farmstead. Stockholm: Almqvist och Wiksell International, 2002.

Andrén, Anders. "Från antiken till antiken-stadsvisioner i Skandinavien före 1700." In Staden, himmel eller helvete-tankar om människan i staden, edited by Anders Andrén, 142-84. Stockholm: Informationsförlaget, 1998.

Arndt, Allan, Wim Van Neer, Bart Hellemans, Johan Robben, and Filip Volckaert. "Roman Trade Relationships at Sagalassos (Turkey) Elucidated by Ancient DNA of Fish Remains." Journal of Archaeological Science 30, no. 9 (2003): 1095-105.

Aronsson, Kjell-Åke. "Pollen Evidence of Saami Settlement and Reindeer Herding in the Boreal Forest of Northernmost Sweden-An Example of Modern Pollen Rain Studies as an Aid in the Interpretation of Marginal Human Interference from Fossil Pollen Data." Review of Palaeobotany and Palynology 82 (1994): 37-45.

Ashby, Steven P., Ashley N. Coutu, and Søren M. Sindbæk. "Urban Networks and Arctic Outlands: Craft Specialists and Reindeer Antler in Viking Towns." European Journal of Archaeology 18, no. 4 (2015): 679-704.

Askeladden, The Norwegian Directorate for Cultural Heritage Database for Archeological Sites and Monuments: https://askeladden.ra.no/ [accessed January 27, 2020].

Barrett, James H., Sanne Boessenkool, Catherine J. Kneale, Tamsin C. O'Connell, and Baastian Star. "Ecological Globalisation, Serial Depletion and the Medieval Trade of Walrus Rostra." Quaternary Science Reviews 229 (2020): 2-15.

Baug, Irene. Quarrying in Western Norway-An Archaeological Study of Production and Distribution in the Viking Period and the Middle Ages. Oxford: Archaeopress, 2015.

Bergman, Ingela and Lars-Erik Edlund. "Birkarlar and Sámi-Inter-Cultural Contacts beyond State Control: Reconsidering the Standing of External Tradesmen (Birkarlar) in Medieval Sámi Societies." Acta Borealia 33, no. 1 (2016): 52-80.

Bergman, Ingela, L. Liedgren, L. Östlund, and O. Zackrisson. "Kinship and Settlements: Sami Residence Patterns in the Fennoscandian Alpine Areas around A.D. 1000." Arctic Anthropology 45 (2008): 97-110.

Bergstøl, Jostein. Samer i Østerdalen? En studie av etnisitet i jernalderen og middelalderen i det nordøstre Hedmark. Oslo: Oslo University, 2008.

Bloch-Nakkerud, Tom. Kullgropen i Jernvinna Øverst i Setesdal. Oslo: Universitetets Oldsaksamling, 1987.

Bolin, Hans. "Två undersökta gravfält i Norrlands inland. En diskussion kring forntida kulturtraditioner i fjällnära miljöer." In Övre Grundsjön, Vojmsjön och Lilla Mark: rapport över arkeologiska undersökningar, edited by Hans Bolin and Roger Edenmo, 6-30. Stockholm: Riksantikvarieämbetet, 2002.

Brunson, Katherine and David Reich. "The Promise of Paleogenomics beyond Our Own Species." Trends in Genetics (2019): 319-29.

Christensen, Arne Emil. “Reinjeger og kammaker, en forhistorisk yrkeskombinasjon?” Viking. Tidsskrift för norrøn arkeologi 49 (1986): 113-33.

Duggan, Anne J., ed. Nobles and Nobility in Medieval Europe: Concepts, Origins, Transformations. Woodbridge: Boydell, 2000.

Emanuelsson, Marie. Settlement and Land-Use History in the Central Swedish Forest Region: The Use of Pollen Analysis in Interdisciplinary Studies. Umeå: Swedish University of Agricultural Sciences, 2001. 
Emanuelsson, Marie, Annie Johansson, Stefan Nilsson, Susanne Pettersson, and Eva Svensson. Settlement, Shieling and Landscape: The Local History of a Forest Hamlet. Stockholm: Almqvist \& Wiksell International, 2003.

Englund, Lars-Erik. Blästbruk: Myrjärnshanteringens förändringer i ett långtidsperspektiv. Stockholm: Jernkontoret, 2002.

Eriksson, Ove. "Origin and Development of Managed Meadows in Sweden: A Review." Rural Landscapes: Society, Environment, History 7, no. 1 (2020).

Ersmark, Erik et al. "Genetic Turnovers and Northern Survival during the Last Glacial Maximum in European Brown Bears." Ecology and Evolution 9, no. 10 (2019): 5891-905.

Gifford-Gonzalez, Diane. "New Ecological Directions: Isotopes, Genetics, Historical Ecology, Conservation." In An Introduction to Zooarchaeology, edited by Diane Gifford-Gonzalez, 503-29. Cham: Springer, 2018.

Gollwitzer, Martin. "Yngre järnålder i fjälltrakterna." In Möten i gränsland: samer och germaner i Mellanskandinavien, edited by Inger Zachrisson, 27-33. Stockholm: Statens historiska museum, 1997.

Gustavsson, Rudolf, Andreas Hennius, and John Ljungkvist. "Are Many Vendel and Viking Period Gaming Pieces Made of Whale Bone?" Fornvännen 110, no. 1 (2015): 51-54.

Hallström, Gustaf. “Den tidigaste järnåldern i Dalarna.” Dalarnas hembygdsbok (1931): 28-98.

Hansson, Anders, Carina Olsson, Jan Storå, and Stig Welinder. Agrarkris och ödegårdar i Jämtland. Östersund: Jamtli, 2005.

Hartnup, Karen et al. "Ancient DNA Recovers the Origins of Māori Feather Cloaks." Molecular Biology and Evolution 28, no. 10 (2011): 2741-50.

Helgesson, Bertil. “Järnålderns Skåne: samhälle, centra och regioner." PhD diss., University of Lund, 2002.

Hennius, Andreas. “Viking Age Tar Production and Outland Exploitation.” Antiquity 92 (2018): 1349-61.

. "Outland Exploitation and the Emergence of Seasonal Settlements." Bebyggelsehistorisk tidskrift 79 (2020): 8-24.

."Towards a Refined Chronology of Prehistoric Pitfall Hunting in Sweden." European Journal of Archaeology 23 (2020): 530-46.

Hennius, Andreas et al. "Whalebone Gaming Pieces: Aspects of Marine Mammal Exploitation in Vendel and Viking Age Scandinavia." European Journal of Archaeology 21 (2018): 612-31.

Hjärthner-Holdar, Eva et al. "Blästbruk-Finns det en systematik mellan tid, rum och typ?" In Ovnstypologi og ovnskronologi i den Nordiske Jernvinna: Jernvinnai Oppland: Symposium på Kittilbu. 16.-18. Juni 2009, edited by Bernt Rundberget, Jan Henning Larsen, and Tom H. Borse Haraldsen, 24-38. Oslo: Portal, 2013.

Hofreiter, Michael et al. "The Future of Ancient DNA: Technical Advances and Conceptual Shifts." BioEssays 37, no. 3 (2015): 284-93.

Hougen, Bjørn. "Jaktfunn fra dalbygdenes folkevandringstid." Universitetets Oldsaksamlings årbok (1930-1932): 51-87.

. Fra seter til gård: studier i norsk bosetningshistorie. Oslo: Norsk arkeologisk selskap, 1947.

Hyenstrand, Åke. "Forntid i gränsland." In Lima och Transtrand: ur två socknars historia, edited by Stig Björklund, 109-66. Malung: Malungs kommun, 1987.

Jesch, Judith. The Viking Diaspora. London: Routledge, 2015.

Karlsson, Hanna, Marie Emanuelsson, and Ulf Segerström. "The History of a Farm-Shieling System in the Central Swedish Forest Region." Vegetation History and Archaeobotany 19 (2010): 103-19. 
Karlsson, Johnny. Spill. Om djur, hantverk och nätverk i Mälarområdet under Vikingatid och Medeltid. Stockholm: Stockholm University, 2016.

KMR [https://app.raa.se/open/fornsok/]: the Swedish National Heritage Board's database for archaeological sites and monuments.

Kvamme, Mons. "Pollen Analytical Studies of Mountain Summer-Farming in Western Norway." In The Cultural Landscape-Past, Present and Future, edited by Hilary H. Birks, H. John B. Birks, Peter E. Kaland, and Dagfinn Moe, 349-67. Cambridge: Cambridge University Press, 1988.

Larsen, Jan Henning. Jernvinneundersøkelser. Oslo: Kulturhistoriskt museum, 2009.

Lindgren, Sakarias. “Mötesplatser i fångstmarken.” Master's thesis, Uppsala University, 2019.

Lindholm, Karl-Johan, Emil Sandström, and Ann-Kristin Ekman. "The Archaeology of the Commons." Journal of Archaeology and Ancient History 10 (2013): 3-49.

Lindholm, Karl-Johan and John Ljungkvist. "The Bear in the Grave-Exploitation of Top Predator and Herbivore Resources in First Millennium Sweden-First Trends from a LongTerm Research Project." European Journal of Archaeology 19 (2016): 3-27.

Lindkvist, Thomas and Kurt Ågren. Sveriges medeltid. Solna: Esselte stadium, 1985.

Ljung, Tomas. Sankt Olof i Dalarna: kult och vallfart. Falun: Dalarnas fornminnes- och hembygdsförbund, 2001.

Ljungkvist, John. "Continental Imports to Scandinavia. Patterns and Changes between 400800 AD." In Foreigners in Early Medieval Europe. Thirteen International Studies on Early Medieval Mobility, edited by Dieter Quast, 263-82. Monographien des Römisch-Germanischen Zentralmuseums 78. Mainz: Römisch-Germanischen Zentralmuseum, 2009.

Loftsgarden, Kjetil. “Kolgroper-Gull Eller Gråstein?” In Arkeologiske Undersøkelser 20052006, edited by Inger Marie Berg-Hansen, 142-54. Oslo: Portal, 2015.

. "Marknadsplassar omkring Hardangervidda-ein arkeologisk og historisk analyse av innlandets økonomi og nettverk i vikingtid og mellomalder." PhD diss., Bergen University, 2017. . "The Prime Movers of Iron Production in the Norwegian Viking and Middle Ages." Fornvännen 114 (2019): 88-100.

."Mass Production and Mountain Marketplaces in Norway in the Viking and Middle Ages." Medieval Archaeology 64, no. 1 (2020): 94-115.

Lunden, Kåre. Norge under Sverreætten, 1177-1319: Høymiddelalder. Oslo: Cappelen, 1976.

Lyngstrøm, Henriette. "Slaggeaftapningsovne i Danmark, udgravninger og forsøg?" In Ovnstypologi og ovnskronologi i den Nordiske Jernvinna: Jernvinnai Oppland: Symposium på Kittilbu. 16.-18. Juni 2009, edited by Bernt Rundberget, Jan Henning Larsen, and Tom H. Borse Haraldsen, 119-34. Oslo: Portal, 2013.

Magnusson, Gert. Lågteknisk järnhantering i Jämtlands län. Stockholm: Stockholm University, 1986.

Magnusson, Gert and Ulf Segerström. "Leva i skogsbygd. När blev människan bofast i Södra Norrland?" Bebyggelsehistorisk tidskrift 57 (2009): 5-25.

Mikkelsen, Egil. Fangstprodukter $i$ vikingetidens og middelalderens økonomi. Organiseringen av massefangst av villrein i Dovre. Oslo: Universitets Oldsaksamling, 1994.

Myhre, Bjørn. "Landbruk, Landskap og Samfunn 4000 F.Kr.-800 E.Kr." In Jorda Blir Levevei: 4000 F.Kr.-1350 E.Kr., edited by Bjørn Myhre and Ingvild Øye, 11-214. Norges Landbrukshistorie. Oslo: Samlaget, 2002.

Myrdal, Janken, ed. Jordbruket under feodalismen: 1000-1700. Det svenska jordbrukets historia 2. Stockholm: Natur och kultur/LT, 1999.

Odner, Knut. Finner och Terfinner. Etniske processer i det nordlige Fenno-Skandinavia. Occasional Papers in Social Anthropology 9. Oslo: Oslo University, 1983. 
Persson, Thomas. "Jag väntar, vid min mila. En studie av förhistorisk träkols- och tjärframställning i Skandinavien.” Bachelor's (Candidate's) thesis, University of Lund, 1994.

Petré, Bo. "Björnfällen i begravningsritualen-statusobjekt speglande regional skinnhandel?" Fornvännen 75 (1980): 5-14.

Pettersson Jensen, Ing-Marie. Norberg och järnet: bergsmännen och den medeltida Industrialiseringen. Stockholm: Stockholm University, 2012.

Ramsey, Christopher Bronk. "Methods for Summarizing Radiocarbon Datasets." Radiocarbon 59, no. 6 (2017): 1809-33.

Ramqvist, Per H. "Utbytessystem under det första årtusendet e.Kr. Idéer utgående från tre mellannorrländska älvar." Fornvännen 96 (2001): 1-21.

. "Fem Norrland: om norrländska regioner och deras interaktion." Arkeologi i norr 10 (2007): 153-80.

Resi, Heid G. "Reflections on Viking Age Local Trade in Stone Products." In Proceedings from the Tenth Viking Congress, Larkollen, Norway 1985, edited by James Knirk, 95-102. Oslo: Universitetets oldsakssamling, 1987.

Risbøl, Ole, Katrine Stene, and Anne Sætren, eds. Kultur og natur i Grimsdalen landskapsvernområde. Sluttrapport fra DYLAN-prosjektet. Norsk institute for kulturminneforsking tema 38. Oslo: NIKU, 2011. Electronic resource.

Rosvold, Jørgen, Gitte Hansen, and Knut H. Røed. "From Mountains to Towns: DNA from Ancient Reindeer Antlers as Proxy for Domestic Procurement Networks in Medieval Norway." Journal of Archaeological Science: Reports 26 (2019): doi.org/10.1016/j.jasrep.2019.05.025.

Rundberget, Berndt. “Jernets dunkle dimension. Jernvinna i sørlige Hedmark. Sentral økonomisk faktor og premiss for samfundsutvikling c. AD 700-1300." PhD diss., Oslo University, 2013.

Rundberget, Bernt, Jan Henning Larsen, and Tom H. Borse Haraldsen, eds. Ovnstypologi og ovnskronologi i den Nordiske Jernvinna: Jernvinnai Oppland: Symposium på Kittilbu. 16.-18. Juni 2009. Oslo: Portal, 2013.

Rydving, Håkan. "The 'Bear Ceremonial' and Bear Rituals among the Khanty and the Sami." Temenos: Nordic Journal of Comparative Religion 46 (2010): 31-52.

Schmidt, Patrick et al. "Birch Tar Production Does Not Prove Neanderthal Behavioral Complexity." Proceedings of the National Academy of Sciences 116, no. 36 (2019): 17707-11.

Scott, James C. Decoding Subaltern Politics: Ideology, Disguise, and Resistance in Agrarian Politics. New York: Routledge, 2013.

Serning, Inga. Dalarnas järnålder. Stockholm: Kungl. Vitterhets-, historie- och antikvitetsakademien, 1966.

Skjølsvold, Arne. "En fangstmanns grav i Trysil-fjellene." Viking. Tidsskrift för norrøn arkeologi 33 (1969): 139-201.

. "Refleksjoner omkring jernaldersgravene i sydnorske fjellstrøk." Viking. Tidsskrift för norrøn arkeologi 44 (1980): 139-201.

Skre, Dagfinn. "Monetary Practices in Early Medieval Western Scandinavia $\left(5^{\text {th }}-10^{\text {th }}\right.$ Centuries AD)." Medieval Archaeology 61, no. 2 (2017): 277-99.

Star, Bastiaan et al. "Ancient DNA Reveals the Arctic Origin of Viking Age Cod from Haithabu, Germany." Proceedings of the National Academy of Sciences 114, no. 34 (2017): 9152-57.

. "Ancient DNA Reveals the Chronology of Walrus Ivory Trade from Norse Greenland." Proceedings of the Royal Society B. Biological Sciences 285 (2018).

Storli, Inger. “Sami Viking Age Pastoralism—or 'The Fur-Trade Paradigm' Reconsidered." Norwegian Archaeological Review 26 (1993): 1-20. 
Stene, Katrine. I randen av taigaen-bosetning og ressursutnyttelse i jernalder og middelalder i Østerdalen. Oslo: Portal, 2014.

Stene, Katrine. "Utmarka-en 'arena' for samfunnsutvikling i middelalder. Massefangst av villrein og jernproduksjon." In Landskaparna, edited by Anders Håkansson and Christina Rosén, 225-43. Halmstad: Kulturmiljö Halland, 2011.

Stenvik, Lars F. "Iron Production in Scandinavian Archaeology." Norwegian Archaeological Review 36 (2003): 119-34.

Stenvik, Lars F. “Trøndelagsovnen—en studie basert på materielle levninger etter Jernframstilling i Midt-Norge." In Ovnstypologi og ovnskronologi i den Nordiske Jernvinna: Jernvinnai Oppland: Symposium på Kittilbu. 16.-18. Juni 2009, edited by Bernt Rundberget, Jan Henning Larsen, and Tom H. Borse Haraldsen, 47-54. Oslo: Portal, 2013.

Støen, Ole-Gunnar et al. "Inversely Density-Dependent Natal Dispersal in Brown Bears Ursus arctos." Oecologia 148, no. 356 (2006): http://doi.org/10.1007/s00442-006-0384-5.

Svensson, Eva. Människor i utmark. Stockholm: Almkvist \& Wiksell, 1998. . The Medieval Household. Daily Life in Castles and Farmsteads. Turnhout: Brepols, 2008. . "Innovations in the Rural Edge. Inventions and Smart Organisations in the Scandinavian Outland Use." In Towns and Villages in Medieval Rus: Archaeology, History, Culture. To Mark the 60th Birthday of the Academician Nikolai Makarov, edited by P. G. Gaidukov et al., 69-77. Moscow: Russian Academy of Sciences, Institute of Archaeology, 2015.

Svensson, Eva and Mark Gardiner. "Introduction: Marginality in the Preindustrial European Countryside." In Medieval Rural Settlement in Marginal Landscapes, edited by Jan Klápště and Petr Sommer, 21-25. Ruralia 7. Turnhout: Brepols, 2009.

Taberlet, Pierre, Jon E. Swenson, Finn Sandegren, and Anders Bjärvall. "Localization of a Contact Zone between Two Highly Divergent Mitochondrial DNA Mineages of the Brown Bear Ursus arctos in Scandinavia." Conservation Biology 9, no. 5 (1995): 1255-61.

Tveiten, Ole and Kjetil Loftsgarden. "The Extensive Iron Production in Norway in the Tenth to Thirteenth Century—a Regional Perspective." In Viking Age Transformations: Trade, Craft and Resources in Western Scandinavia, edited by Zanette T. Glørstad and Kjetil Loftsgarden, 111-23. Oxford: Routledge, 2017.

Villstrand, Nils. "En räddande eld. Tjärbränning inom det svenska riket 1500-1800." In Tjära, barkbröd och vildhonung: utmarkens människor och mångsidiga resurser, edited by Britt Liljewall, 62-77. Stockholm: Nordiska museet, 1996.

Vretemark, Maria. Från ben till boskap: kosthåll och djurhållning med utgångspunkt i medeltida benmaterial från Skara. D. 1. Stockholm: Stockholm University, 1997.

Wehlin, Joakim. "Fångstmarkens folk." In Arkeologi i Dalarna, edited by Eva Carlsson, 218-50. Falun: Dalarnas fornminnes- och hembygdsförbund, 2016.

. "Fäbodarnas historia." Dalarnas hembygdsbok 89 (2019): 16-30.

Wehlin, Joakim, Rebecka Teglind, Sabine Sten, and Eva Carlsson. "Avrättningar och centralmakt i Stora Tuna i Dalarna under den tidiga medeltiden. Nya analyser av benen från Kyrkskolan." Fornvännen 113 (2019): 196-209.

Welinder, Stig. Jämtarna och Samerna kom först. Östersund: Jamtli, 2008.

White, Lynn. Medieval Technology and Social Change. London: Oxford University Press, 1964.

Xenikoudakis, Georgios, Erik Ersmark, Jean-Luc Tison, Lisette Waits, Jonas Kindberg, Jon E. Swenson, and Love Dalén. "Consequences of a demographic bottleneck on genetic structure and variation in the Scandinavian brown bear." Molecular Ecology 24, no. 13 (2015): 3441-54.

Zachrisson, Inger, ed. Möten i gränsland: samer och germaner i Mellanskandinavien. Stockholm: Statens historiska museum, 1997. 
"Vittnesbörd om pälshandel? Ett arkeologiskt perspektiv på romerska bronsmynt funna i norra Sverige." Fornvännen 105 (2010): 188-202.

Zachrisson, Inger and Elisabet Iregren. Lappish Bear Graves in Northern Sweden: An Archaeological and Osteological Study. Stockholm: Kungl. Vitterhets-, historie- och antikvitetsakademien, 1974.

Karl-Johan Lindholm (karl-johan.lindholm@arkeologi.uu.se) is Associate Professor in the Department of Archaeology and Ancient History at Uppsala University. His main research interest is to bridge the socio-environmental interface through interdisciplinary research and long-term understandings of landscapes and land-use in agriculturally marginal regions. He applies historical ecology, integrated landscape analysis, and critical historical analysis in order to situate current landscape policy in historical contexts with a bearing on current approaches to the sustainable management of biocultural heritage. An additional interest is the combination of archaeology with rural development and landscape studies to aid further understanding of past and present forms of collective action.

Erik Ersmark (erik.ersmark@nrm.se) is a postdoctoral researcher currently working at the Centre for Paleogenetics in Stockholm. He completed his PhD in 2016 at Stockholm University, with a thesis entitled "Large Carnivore Population Turnover and Ecological Change during the Late Quaternary." His research interests lie in the area of ancient DNA applications, ranging from wet lab methods to ecological implementations, and his work has focused on large carnivores, especially the brown bear (Ursus arctos). He has also taken part in several projects dealing with communicating DNA research, for example giving popular science lectures and teaching implementations of both ancient and environmental DNA.

Andreas Hennius (andreas.hennius@arkeologi.uu.se) is a $\mathrm{PhD}$ candidate in the Department of Archaeology and Ancient History at Uppsala University. His research interests are the fundamental societal changes that took place during the Middle Iron Age. His doctoral dissertation, "Outlanders? Resource Colonisation, Raw Material Exploitation and Networks in Middle Iron Age Sweden," will be published in 2021 and uses an outland perspective to gain a deeper understanding of the developments seen in both agrarian regions and marginal outland areas. By using different types of source materials, he shows the interdependencies between these different types of environments.

Sakarias Lindgren (sakarias.lindgren@gmail.com) is currently working as field archaeologist for The Arctic University Museum of Norway (UiT). His main research interests concern land use, agrarian history, and exchange networks during the Middle and Late Iron Age (ca. 0-800 CE) in northern Europe. Landscape archaeology and spatial analysis constitute the main foundation of this research. 
Kjetil Loftsgarden (kjetil.loftsgarden@khm.uio.no) is Associate Professor in the Museum of Cultural History at the University of Oslo. His area of expertise is the Late Iron Age to the early Middle Ages, focusing on iron production, trade, meeting- and market-places, and networks; as well as the consequences of climatic and environmental changes in Iron Age Scandinavia and their effects on population numbers, settlement patterns, agricultural practices, and social structures. He utilizes large-scale archaeological data to develop spatial and statistical analyses and models to broaden our understanding of societal and socio-economic developments in this era.

Eva Svensson (Eva.Svensson@kau.se) is a Professor in the Department of Political, Historical, Religious, and Cultural Studies at Karlstad University. She is an expert in social, ecological, and interdisciplinary approaches to studying forested landscapes in a long-term perspective, with a focus on the Viking Age through the early modern era. She is also doing research on subaltern environments and lifescapes in the eighteenth to twentieth centuries, the role of heritage and nature in community-building and rural development, and the role of heritage and history in realizing The United Nations' 2030 Agenda for Sustainable Development.

Abstract In this article, we present ongoing archaeological research into Scandinavia's forested inland region, suggesting that its people and communities were socially and economically integrated into systems of trade and in close interaction with the worlds outside, as early as the first centuries of the Common Era. The article presents a range of archaeological evidence, from ca. 500 to $1400 \mathrm{CE}$, for processes of ecological globalization, manifested by the exploitation of local landscapes and the extraction of valued products that could be transformed into commodities through crafts and trade. These forested landscapes were reliant on-and also shaped by-complex social and economic relations reflecting interrelated socio-economic systems of extraction, production, and consumption. Our main argument is that these landscapes are crucial to identifying and understanding the contours of the premodern global North.

Keywords archaeology, boreal forest, Scandinavia, ecological globalization, resource colonization, tar, iron, brown bears, Viking Age, Iron Age, communication networks 